\title{
Comparative Study of Bone Marrow and Blood B Cells in Infantile and Acquired Agammaglobulinemia
}

\author{
POSSIBLE ROLE OF CIRCULATING ANTI-IGM \\ IN PATHOGENESIS
}

\author{
Nabih I. Abdou, Salvatore R. Casella, Nancy L. Abdou, and \\ Ises A. Abrahamsohn \\ From the Division of Allergy and Immunology, Department of Medicine, \\ School of Medicine, University of Pennsylvania, Veterans Administration \\ Hospital, Philadelphia, and Hematology Section, Philadelphia General \\ Hospital, University of Pennsylvania Service, \\ Philadelphia, Pennsylvania 19174
}

\begin{abstract}
A в S T RAC T The status of immunoglobulin (Ig) receptors of the bone marrow dependent $(B)$ cells present in either the bone marrow (BM) or peripheral blood (PB) of three patients with infantile agammaglobulinemia (I-AGG), or seven patients with acquired agammaglobulinemia (A-AGG) is compared with those of 12 controls. Quantitative and qualitative changes of the different classes of Ig receptors on B cells were evaluated by their capacity to bind $\left[{ }^{125} \mathrm{I}\right]$ anti-Ig, to be stained with fluorescinated anti-Ig and their in vitro proliferative capacity upon incubation with the anti-Ig. Patients with I-AGG lacked B cells in both the BMI and PB. Whereas BM cells of patients with A-AGG carried receptors similar to control cells, their blood B cells had fewer IgM, IgG, and IgA cells which failed to proliferate in vitro in the presence of the anti-Ig. An anti-Ig.M of the IgG class was detected in the sera of patients with A-AGG but not in sera of I-AGG. The isolated anti-IgM agglutinated human red cells coated with IgM. The anti-IgM partially blocked the binding of fluorescinated or radiolabeled anti-IgM to Ig MI peripheral blood lymphocytes of normal controls. The eluted anti-IgM in presence of complement was partially cytotoxic to normal cells. It is concluded that I-AGG-B cell defect is due to failure of $B$ cell development in
\end{abstract}

This work was presented in part to the Eastern Section of American Federation for Clinical Research, Philadelphia, Pa., December, 1971.

Received for publication 22 February 1973 and in revised form 11 April 1973. the bone marrow compartment whereas the peripheral exclusion of IgAl cells by an anti-IgM with the subsequent failure of differentiation of both $\operatorname{IgG}$ and $\operatorname{IgA}$ cells could be an important mechanism in A-AGG-B cell defect.

\section{INTRODUCTION}

Narkers of bone marrow-dependent (B) ${ }^{1}$ cells in man have been identified in both the bone marrow (1) and peripheral blood (2) compartments and are universally accepted to be surface immunoglobulins ( Ig). B cells are not in a static state but undergo changes upon maturation. migration between the various lymphoid compartments. and upon interaction with the specific antigen $(3,4)$. Subpopulations of B cells have recently been described in the mouse system and were proposed to represent various degrees of maturation of the B cell system (5). Recent studies have indicated that B cell development within the stem cell compartment is independent of antigen stimulation (6) and that IgM-B cells control the differentiation of both $\operatorname{IgG}$ and $\operatorname{IgA}$ cells $(7)$ and are the main recognition units (8).

The purpose of this paper is to compare and characterize the $\mathrm{B}$ cell abnormality in both the bone marrow

1 Abbreviations used in this paper: AGG, agammaglobulinemia ; A-AGG, acquired AGG; $\mathrm{B}$, bone marrow dependent ; GG, gammaglobulin; Ig, immunoglobulin; I-AGG, infantile AGG; K, kappa chain; NGGG, normal goat gamma globulin; SI, specific incorporation; $\mathrm{T}$, thymus dependent. 


\begin{tabular}{|c|c|c|c|c|c|c|c|}
\hline \multirow{3}{*}{$\begin{array}{l}\text { Disease state } \\
\text { (no. studied) }\end{array}$} & \multirow{2}{*}{\multicolumn{3}{|c|}{ Quantitative Ig }} & \multicolumn{2}{|c|}{ Antibody testing } & \multicolumn{2}{|c|}{ Delayed skin testing } \\
\hline & & & & \multirow{2}{*}{$\begin{array}{l}\text { Secondary*- } \\
\text { diphtheria and } \\
\text { tetanus }\end{array}$} & \multirow{2}{*}{$\begin{array}{l}\text { Primary } t- \\
\text { KLH }\end{array}$} & \multirow{2}{*}{$\begin{array}{l}\text { Secondary } \delta- \\
\text { PPD, cand., } \\
\text { mumps }\end{array}$} & \multirow{2}{*}{$\begin{array}{c}\text { Primary } \|- \\
\text { DNCB }\end{array}$} \\
\hline & G & $\mathbf{M}$ & A & & & & \\
\hline & & $m g / 100 m l$ & & $u$ & & & \\
\hline $\begin{array}{c}\text { Infantile AGG } \\
\text { (3) }\end{array}$ & $<5-15$ & $<2$ & $<4$ & $<1(3)$ & $<10$ & 2 & 3 \\
\hline $\begin{array}{c}\text { Acquired AGG } \\
\text { (7) }\end{array}$ & $<5-105$ & $<2-19$ & $<4-10$ & $\begin{array}{r}<1(5) \\
2(2)\end{array}$ & $<10-80$ & 6 & 7 \\
\hline $\begin{array}{r}\text { Controls } \\
(12)\end{array}$ & $950-1,620$ & $85-115$ & $160-210$ & 5-10 (12) & $1,280-10,000$ & 12 & 12 \\
\hline
\end{tabular}

* Serum antibody titers by the hemagglutination technique were assayed 10 days following injection of diphtheria-tetanus toxoid. Number of patients is in parentheses.

$\$ 1 \mathrm{mg}$ Keyhole limpet hemocyanin $(\mathrm{KLH})$ was used for primary sensitization. Serum anti-KLH titers were determined on the 10th day by the passive hemagglutination technique.

$\S$ Patients were skin tested with PPD, Candida albicans (Hollister-Stier), and mumps (Eli Lilly). Induration was read $48 \mathrm{~h}$ later. Numbers shown are those of patients who showed positive skin test $(>10 \mathrm{~mm})$ to at least one of the three antigens.

\| Sensitization done with $0.1 \mathrm{ml}$ of $5 \%$ solution of dinitrochlorobenzene (DNCB) and followed 2 wk later by challenge with $0.1 \mathrm{ml}$ of $0.005 \%$ solution of DNCB. Skin induration $(>10 \mathrm{~mm}) 48 \mathrm{~h}$ following challenge was considered positive.

and blood compartments of patients with infantile agammaglobulinemia (I-AGG) to cells obtained from patients with acquired agammaglobulinemia (A-AGG) and to search for possible etiologic factors that could be responsible for the $\mathrm{B}$ cell abnormalities.

\section{METHODS}

Patients. Patients' data are summarized in Table $\mathrm{I}$. Two groups of patients were studied: (a) Three cases of I-AGG; boys age 2, 3, and $6 \mathrm{yr}$ who had low Ig levels in their serum, using the low level commercial immunoplates. They were first diagnosed at age 9-12 mo. They had repeated respiratory tract and skin infections and were maintained on monthly GG injections. (b) Seven cases age 24-51 yr, with A-AGG. They had normal infancy and childhood and 2-14 yr history of repeated sinupulmonary and skin infections. Five of those seven cases had recurrent diarrhea, and four of those had biopsy evidence of intestinal lymphoid hyperplasia. (c) Controls were 12 patients with iron deficiency anemia: hemoglobin 9.5-11.2 $\mathrm{g}$ matched for the age of the patients with AGG, without history of repeated infections and had serum Ig levels within the normal range. None of the patients in the three groups described, had abnormal values of total hemolytic complement or of the third component of complement (C3). Serum antibody responses 10 days following sensitization with a primary antigen, Keyhole limpet hemocyanin, KLH (Pacific Bio-Marine Supply Co., Venice, Calif.) and to secondary antigens, tetanus-diphtheria toxoid (Wyeth Laboratories, Marietta, Pa.) were evaluated (Table I). Cell-mediated immunity as manifested by delayed skin induration to tuberculin (Connaught Laboratory, Toronto, Ontario, Canada), mumps (Eli Lilly \& Co., Indianapolis, Ind.), Candida albican (Hollister-Stier Laboratories Inc., Philadelphia, Pa.) and to dinitrochlorobenzene (Eastman Kodak, Rochester,
N. Y.) were also evaluated in all patients and controls (Table I).

Quantitative immunoglobulins and complement assays. Normal and low level quantitative immunoglobulin plates and C3 immunoplates (Kallestad Laboratories, Inc., St. Paul, Minn.) were used. Total hemolytic complement assay was determined by the conventional technique (9).

Preparation of cell suspensions and cell cultures. The techniques of bone marrow and blood collection, preparation of cell suspensions and the culture technique were reported earlier $(1,8,10)$. Briefly, bone marrow aspirates or peripheral blood were collected in heparinized plastic syringes and lymphocyte rich (79-92\%) suspensions were prepared by means of sucrose plasma linear density gradients (8). In all the experiments described $10 \mu \mathrm{g}$ or $100 \mu \mathrm{g}$ of light chain-absorbed, goat anti-human heavy chain-specific Ig antisera were added to $10^{8}$ lymphocytes suspended in $1 \mathrm{ml}$ medium 199 containing 10\% GG-free pooled human AB serum (10).

Iodination of anti-Ig antisera. The techniques of iodination and binding of the $\left[{ }^{125} \mathrm{I}\right]$ anti-Ig to cells have been described previously (10). Briefly $1 \mathrm{mg}$ of the anti-Ig or normal goat GG (NGGG) was allowed to interact for $5 \mathrm{~min}$ with $1 \mathrm{mCi}$ of ${ }^{125} \mathrm{I}$ (International Chemical and Nuclear Corp., Irvine, Calif.) in the presence of Chloramine-T (11). To test for the binding of cells to the labeled proteins, one million lymphocytes were incubated for $1 \mathrm{~h}$ at $4^{\circ} \mathrm{C}$ under continuous gentle rotation with $10 \mu \mathrm{g}$ of the labeled protein. The cells were then washed three times with medium 199 and counted in the gamma counter. The results are expressed as the ratio of counts per minute (cpm) of cells in the presence of $\left[{ }^{125} \mathrm{I}\right]$ anti-Ig over the $\mathrm{cpm}$ in the presence of [ $\left.{ }^{225} \mathrm{I}\right]$ NGGG.

Staining with fluorescinated anti-Ig. Peripheral blood or bone marrow rich lymphocyte cell suspensions were incubated with heavy chain-specific, fluorescinated anti-IgG, $-\mathrm{M}$, or -A (Behring Diagnostic Inc., Woodbury, N. Y.) 
TABLE II

Binding of ${ }^{125}$ I-Anti-Immunoglobulin to Bone Marrow or Blood Lymphocytes

\begin{tabular}{|c|c|c|c|c|c|c|}
\hline \multirow{3}{*}{$\begin{array}{l}\text { Disease state } \\
\text { (no. tested) }\end{array}$} & \multicolumn{6}{|c|}{ Specific binding to $\left[{ }^{125} \mathrm{I}\right]$ anti-Ig* } \\
\hline & \multicolumn{3}{|c|}{ Bone marrow } & \multicolumn{3}{|c|}{ Blood } \\
\hline & $\mathbf{M}$ & G & $A$ & $\mathrm{M}$ & G & $A$ \\
\hline $\begin{array}{c}\text { Infantile-AGG } \\
\text { (3) }\end{array}$ & $\begin{array}{c}1.3-2.1 \\
(1.8) \ddagger\end{array}$ & $\begin{array}{r}(0.9-1.9 \\
(1.3) \ddagger\end{array}$ & $\begin{array}{r}1.1-1.6 \\
(1.4) \ddagger\end{array}$ & $\begin{array}{r}1.4-2.0 \\
(1.8)_{+}^{+}\end{array}$ & $\begin{array}{c}0.9-1.5 \\
(1.1) \ddagger\end{array}$ & $\begin{array}{c}1.8-2.3 \\
(1.9)_{+}^{+}\end{array}$ \\
\hline $\begin{array}{c}\text { Acquired AGG } \\
(6)\end{array}$ & $\begin{array}{c}9.2-15.7 \\
(12.3 \pm 2.1)\end{array}$ & $\begin{array}{c}5.0-7.4 \\
(6.3 \pm 0.7)\end{array}$ & $\begin{array}{c}3.6-5.1 \\
(4.4 \pm 0.9)\end{array}$ & $\begin{array}{c}1.3-1.8 \\
(1.5 \pm 0.2) \S\end{array}$ & $\begin{array}{l}2.7-4.1 \\
(3.4 \pm 0.7) \ddagger\end{array}$ & $\begin{array}{l}1.5-3.9 \\
(2.3 \pm 0.4) \ddagger\end{array}$ \\
\hline $\begin{array}{r}\text { Controls } \\
\text { (12) }\end{array}$ & $\begin{array}{c}8.7-17.4 \\
(12.3 \pm 2.9)\end{array}$ & $\begin{array}{c}6.7-7.9 \\
(7.1 \pm 2.1)\end{array}$ & $\begin{array}{c}3.7-5.4 \\
(4.9 \pm 0.7)\end{array}$ & $\begin{array}{c}6.3-9.8 \\
(7.9 \pm 1.2)\end{array}$ & $\begin{array}{c}12.4-21.6 \\
(14.7 \pm 3.2)\end{array}$ & $\begin{array}{c}5.2-13.7 \\
(9.2 \pm 1.7)\end{array}$ \\
\hline
\end{tabular}

* Ratio of counts per minute (cpm) of lymphoid cells in the presence of $\left[{ }^{125} \mathrm{I}\right] \mathrm{anti}-\mathrm{Ig}$ over cpm in the presence of ${ }^{125} \mathrm{I}$ labeled normal goat GG (NGGG). $10 \mu \mathrm{g}$ of [ $\left.{ }^{125} \mathrm{I}\right]$ anti-Ig added to $10^{6}$ lymphoid cells gave $0.9 \pm 0.11 \times 10^{5} \mathrm{cpm}$ prior to washing the cells. Controls' cells incubated with $\left[{ }^{125} \mathrm{I}\right] \mathrm{NGGG}$ and washed three times gave $104 \pm 21 \mathrm{cpm}$. Ranges, means, and SE were given. No SE were given for groups of patients below 6.

$\ddagger$ Significantly different $(P<0.01)$ from control values.

$\$$ Significantly different $(P<0.01)$ from control values and from values of binding of bone marrow to $\left[{ }^{125} \mathrm{I}\right] \mathrm{anti} I g . \mathrm{II}$.

for $30 \mathrm{~min}$ at $4^{\circ} \mathrm{C}$. The monospecificity of the antisera after being absorbed with light chains were tested by immunoelectrophoresis prior to use. The specificity was also tested by blocking the staining by means of monospecific nonfluorescinated anti-Ig. Following staining with the fluorescinated anti-Ig, the cells were washed three times with chilled phosphate-buffered saline (PBS, pH 7.2) and fluorescence was read by Leitz fluorescence microscope (E. Leitz Inc., Rockleigh, N. J.) using HBO 200 mercury are, BG 12 excitation filter, and 510 barrier filter.

Detection and quantitation of Anti-Ig. The patients' sera were adsorbed by means of a specific immunoadsorbent according to the method described in detail by us earlier (12). The insoluble immunoadsorbent in this study was prepared by cross-linkage of glutaraldehyde to the Ig which was purchased (Meloy Laboratories Inc., Sprinfield, Va.) and tested for monospecificity by immunoelectrophoresis.
Following exhaustive adsorption of $10 \mathrm{ml}$ of the various patients' or control sera, the columns were eluted with $20-50$ $\mathrm{ml}$ of $0.1 \mathrm{M}$ glycine $\mathrm{HCl}$, the material is then concentrated to $1 \mathrm{ml}$ and examined for the presence of $\mathrm{Ig}$ using the low level Ig quanti-plates (Kallestad Laboratories). The amounts of the anti-Ig were expressed as $\mathrm{mg} / 100 \mathrm{ml}$ of the original serum sample.

Studies of eluted anti-Igs. The binding capacity of the eluted anti-Ig to cells was tested by incubating the eluted material with peripheral blood lymphocytes of controls. 10 or $100 \mu \mathrm{g}$ of the eluted material was incubated under continuous rotation for $1 \mathrm{~h}$ at $4^{\circ} \mathrm{C}$ with $10^{\circ}$ lymphocytes. Cells were then washed three times with medium 199 containing $10 \% \mathrm{GG}$-free plasma. The presence of $\mathrm{Ig}$ receptors on the washed cells was then examined by the capacity of cells to bind to the radiolabeled anti-Ig or be stained with the fluorescinated anti-Ig as described above. Viability studies

TABLE III

Percentage of Bone Marrow or Blood Lymphoid Cells Stained with Fluorescinated Anti-immunoglobulins

\begin{tabular}{|c|c|c|c|c|c|c|}
\hline \multirow{3}{*}{$\begin{array}{l}\text { Disease state } \\
\text { (no. studied) }\end{array}$} & \multicolumn{6}{|c|}{ Percent of stained cells with fluorescinated anti-Ig* } \\
\hline & \multicolumn{3}{|c|}{ Bone marrow } & \multicolumn{3}{|c|}{ Blood } \\
\hline & $\mathbf{M}$ & G & $A$ & $M$ & G & $A$ \\
\hline $\begin{array}{c}\text { Infantile-AGG } \\
\text { (3) }\end{array}$ & $\begin{array}{l}0-2 \\
(1) \ddagger\end{array}$ & $\begin{array}{l}0-4 \\
(2.3) \ddagger\end{array}$ & $\begin{array}{c}1-3 \\
(1.7)\end{array}$ & $\begin{array}{l}0-1 \\
(0.7) \ddagger\end{array}$ & $\begin{array}{c}0-1 \\
(0.3) \ddagger\end{array}$ & $\begin{array}{l}0-2 \\
(1.3) \ddagger\end{array}$ \\
\hline $\begin{array}{l}\text { Acquired AGG } \\
\text { (4) }\end{array}$ & $\begin{array}{c}12-23 \\
(17)\end{array}$ & $\begin{array}{l}5-11 \\
(9)\end{array}$ & $\begin{array}{l}0-2 \\
(1)\end{array}$ & $\begin{array}{l}0-7 \\
(3) \S\end{array}$ & $\begin{array}{l}2-7 \\
(4) \ddagger\end{array}$ & $\begin{array}{l}0-4 \\
(3)\end{array}$ \\
\hline $\begin{array}{r}\text { Controls } \\
(8)\end{array}$ & $\begin{array}{c}19-27 \\
(21 \pm 4.1)\end{array}$ & $\begin{array}{c}5-10 \\
(7.4 \pm 1.3)\end{array}$ & $\begin{array}{c}1-4 \\
(2.1 \pm 0.7)\end{array}$ & $\begin{array}{c}7-13 \\
(9.4 \pm 2.7)\end{array}$ & $\begin{array}{c}11-31 \\
(23.4 \pm 2.9)\end{array}$ & $\begin{array}{c}3-8 \\
(5.6 \pm 1.2)\end{array}$ \\
\hline
\end{tabular}

* Means \pm SE were given between brackets. No SE were given for group of patients below 6.

$\ddagger$ Significantly different $(P<0.01)$ when compared with control values.

$\$$ Significantly different $(P<0.01)$ from values of bone marrow cells of acquired AGG patients stained with anti-IgM 
TABLE IV

In Vitro Proliferative Responses of Bone Marrow or Blood Lymphoid Cells to Various

Anti-immunoglobulin Antisera

\begin{tabular}{|c|c|c|c|c|c|c|}
\hline \multirow{3}{*}{$\begin{array}{l}\text { Disease state } \\
\text { (no. tested) }\end{array}$} & \multicolumn{6}{|c|}{$\mathrm{SI}^{*}$ in presence of anti-Ig } \\
\hline & \multicolumn{3}{|c|}{ Bone marrow } & \multicolumn{3}{|c|}{ Blood } \\
\hline & $\mathbf{M}$ & G & $A$ & $\mathbf{M}$ & G & A \\
\hline $\begin{array}{c}\text { Infantile AGG } \\
\text { (3) }\end{array}$ & $\begin{array}{c}0.8-1.4 \\
(1.1)\end{array}$ & $\begin{array}{c}1.3-2.1 \\
(1.9)\end{array}$ & $\begin{array}{l}0.7-1.1 \\
(0.8)\end{array}$ & $\begin{array}{r}1.3-2.1 \\
(1.7) \ddagger\end{array}$ & $\begin{array}{r}1.1-1.5 \\
(1.3) \ddagger\end{array}$ & $\begin{array}{r}1.0-1.4 \\
(1.1) \ddagger\end{array}$ \\
\hline $\begin{array}{c}\text { Acquired AGG } \\
\text { (7) }\end{array}$ & $\begin{array}{c}1.2-1.7 \\
(1.5 \pm 0.2)\end{array}$ & $\begin{array}{c}0.9-1.4 \\
(1.1 \pm 0.1)\end{array}$ & $\begin{array}{c}1.1-1.6 \\
(1.4 \pm 0.2)\end{array}$ & $\begin{array}{c}1.0-1.4 \\
(1.1 \pm 0.1) \ddagger\end{array}$ & $\begin{array}{c}1.9-2.7 \\
(2.2 \pm 0.2)\end{array}$ & $\begin{array}{c}1.0-1.8 \\
(1.5 \pm 0.1)\end{array}$ \\
\hline $\begin{array}{r}\text { Controls } \\
\text { (12) }\end{array}$ & $\begin{array}{c}1.0-1.5 \\
(1.3 \pm 0.2)\end{array}$ & $\begin{array}{c}0.8-1.6 \\
(1.1 \pm 0.2)\end{array}$ & $\begin{array}{c}0.8-1.5 \\
(1.2 \pm 0.2)\end{array}$ & $\begin{array}{c}3.2-5.9 \\
(4.7 \pm 0.7)\end{array}$ & $\begin{array}{c}4.2-7.9 \\
(5.8 \pm 1.2)\end{array}$ & $\begin{array}{c}2.1-3.7 \\
(2.9 \pm 0.3)\end{array}$ \\
\hline
\end{tabular}

* SI $=$ specific incorporation $=$ ratio of counts $/ \mathrm{min}$ of incorporated $\left[{ }^{3} \mathrm{H}\right]$ thymidine of cells cultured in presence of the $10 \mu \mathrm{g}$ anti-Ig over those cultured in presence of $10 \mu \mathrm{g}$ of normal goat gammaglobulin. The latter counts $/ \mathrm{min}$ were $127 \pm 51$. Means $\pm \mathrm{SE}$ are given. No SE were given for groups of patients below 6.

$\ddagger$ Significantly different $P<0.01$ when compared with control values.

were done as follows. Lymphocytes of controls after being treated with the eluted anti-IgM and washed were incubated for $\frac{1}{2} \mathrm{~h}$ at $37^{\circ} \mathrm{C}$ with $1: 10$ dilution of fresh guinea pig serum. Cells were then washed and one drop of $1 \%$ trypan blue dye was added. The percent of cells that failed to exclude the dye were counted. Among cells not treated with complement $1-3 \%$ were stained.

Hemagglutination assay. Group $\mathrm{O}, \mathrm{Rh}$-positive human red cells were used for the assay. The red cells were coated with $\operatorname{IgM}$ at a concentration of $1 \mathrm{mg} / \mathrm{ml}$ with the chromic chloride method (13). Successful coating of the red cells was tested by the commercial anti-IgM. The hemagglutination titer of the eluted material was assayed in disposable Vshaped microtiter trays after incubating the trays overnight at $4^{\circ} \mathrm{C}$. The titer recorded was the lowest doubling dilution of the eluate which gave agglutination of the coated cells. Titers less than 4 were considered negative.

\section{RESULTS}

Table I shows that both the primary and secondary serum antibody responses in both types of AGG were poor. Cell-mediated immunity as expressed by induration following skin testing with primary or secondary antigens, on the other hand, were comparable to controls.

Table II shows the binding capacity of bone marrow or blood lymphocytes to the iodinated anti-IgM, antiIgG, or anti-IgA. It could be seen that both $B M$ and PB cells from I-AGG patients failed to bind to any of the three labeled antisera as compared with control cells $(P<0.01)$. There were no differences between the binding capacity of BM cells of A-AGG patients to that of control BM cells. The binding capacity of $\mathrm{PB}$ cells of A-AGG patients, however, was poor as compared with controls $(P<0.01)$. Moreover the binding of $\left[{ }^{125} \mathrm{I}\right]$ anti-IgM to blood lymphocytes of A-AGG patients was significantly lower than that to bone marrow cells of the same patients or to the controls $(P<0.01)$.

In Table III is shown the results of staining both bone marrow or blood lymphocytes with fluorescinated

TABLE V

Eluted Anti-Ig of Various Sera: Characterization and Quantitation

\begin{tabular}{|c|c|c|c|c|c|}
\hline \multirow{2}{*}{$\begin{array}{c}\text { Patient } \\
\text { no. }\end{array}$} & \multirow{2}{*}{$\begin{array}{c}\text { Serum } \\
\text { IgG } \\
\text { level }\end{array}$} & \multicolumn{3}{|c|}{ IgG eluted from immunoadsorbent* } & \multirow{2}{*}{$\begin{array}{c}\text { HAt } \\
\text { titer }\end{array}$} \\
\hline & & $\mathbf{M}$ & $\mathbf{G}$ & A & \\
\hline
\end{tabular}

$\begin{array}{crrllr}\text { A-AGG } & & & & & \\ 1 & <5 & 0.7 & \text { ND } & \text { ND } & 8 \\ 2 & 70 & 1.5 & \text { ND } & \text { ND } & 64 \\ 3 & 55 & 1.1 & \text { ND } & \text { ND } & 128 \\ 4 & 90 & 2.9 & \text { ND } & \text { ND } & 512 \\ 5 \| & 100 & 3.1 & \text { ND } & 1.2 & 256 \\ 6 & 90 & 1.7 & \text { ND } & \text { ND } & 256 \\ 7 \| & 105 & 0.9 & \text { ND } & 2.3 & 32 \\ \text { I-AGG } & & & & & \\ 1 \| & <5 & \text { ND } & \text { ND } & 0.5 & 0 \\ 2 \| & 11 & \text { ND } & \text { ND } & 0.9 & 0 \\ 3 \| & 15 & \text { ND } & \text { ND } & 1.4 & 0\end{array}$

* The eluted material is tested by low level Ig plates. The results are expressed as $\mathrm{mg} / 100 \mathrm{ml}$ of the original serum sample.

$\ddagger$ Reciprocal of the lowest dilution showing hemagglutination. Titers less than 4 were considered 0.

$\S$ Not detected.

II Patients who had anaphylactic-like reactions to gamma globulin therapy. 
TABLE VI

Blocking or Cytotoxic Effects of Eluted Anti-immunoglobulins from Sera of Acquired

Agammaglobulinemia Patients on Control Cells

\begin{tabular}{|c|c|c|c|c|c|c|c|}
\hline \multirow{2}{*}{$\begin{array}{l}\text { Eluted } \\
\text { anti-Ig* }\end{array}$} & \multicolumn{3}{|c|}{$\%$ Fluorescinated cells } & \multicolumn{3}{|c|}{ Binding to $[125 I]$ anti-Ig $\ddagger$} & \multirow{2}{*}{$\begin{array}{c}\text { Cytotoxicity } \delta- \\
\% \text { stained } \\
\text { cells }\end{array}$} \\
\hline & M & G & $A$ & $\mathbf{M}$ & G & A & \\
\hline \multicolumn{8}{|l|}{$\mu g$} \\
\hline None & $7-13$ & $11-31$ & $3-8$ & $6.3-9.8$ & $12.4-21.6$ & $5.3-13.7$ & $1-2$ \\
\hline 10 & $2-5$ & $37-53$ & $4-9$ & $3.4-7.9$ & $16.9-31.9$ & $7.1-12.9$ & $9-17$ \\
\hline 100 & $1-2$ & $30-60$ & $5-8$ & $3.1-7.2$ & $19.1-37.5$ & $11.2-14.9$ & $8-25$ \\
\hline
\end{tabular}

* The eluted anti-Ig is incubated for $1 \mathrm{~h}$ at $4^{\circ} \mathrm{C}$ with $10^{6}$ lymphocytes under continuous rotation. Cells were then washed and either stained with fluorescinated anti-Ig or allowed to bind to the [125I]anti-Ig.

$\ddagger$ Ratio of counts/min (cpm) of cells incubated with $\left[{ }^{125} \mathrm{I}\right]$ anti-Ig over $\mathrm{cpm}$ in the presence of $\left[{ }^{125} \mathrm{I}\right]$ NGGG.

Cells incubated with [ $\left.{ }^{125} \mathrm{I}\right]$ NGGG and washed three times gave $147 \pm 19 \mathrm{cmp}$.

$\S$ Percent of cells that failed to exclude the dye.

anti-Ig. Except for the $\operatorname{IgA}$ cells, the percentage of stained cells confirm the findings shown in Table II.

The in vitro proliferative responses of bone marrow or blood lymphocytes in the presence of $10 \mu \mathrm{g}$ of the various anti-Ig antisera is shown in Table IV. It could be seen that cells of both compartments and obtained from both types of AGG patients and bone cells of controls failed to proliferate in vitro. The responses of blood lymphocytes of A-AGG patients to the anti-Ig MI were significantly lower than those of controls $(P=$ $0.0136)$. Though the responses of blood lymphocytes of A-AGG patients to anti-IgG and to anti-IgA were lower than those of controls, the values were not statistically significant $(P>0.05)$. Similar results were obtained upon incubating the cells with $100 \mu \mathrm{g}$ of the anti-Ig (not shown in the Table).

In Table $\mathrm{V}$ is shown the quantity and class of the Ig that could be eluted from $10 \mathrm{ml}$ of the various sera by means of the specific immunoadsorbents. The results are expressed as milligrams per $100 \mathrm{ml}$ of the serum sample. An anti-IgM of the IgG class could be detected in the sera of all A-AGG patients but not from those of I-AGG. The percentage of IgG in the eluted material ranged between 2.1 and $10 \%$ of the total IgG in the serum. Sera from the three patients with I-AGG and from two patients with A-AGG who had anaphylactic-like reactions following GG and/or plasma therapy showed detectable quantities of anti-IgA of the IgG class. The percentage of the eluted IgG ranged from 8.2 to $10 \%$ of the total IgG in the serum. No anti-Ig could be eluted from sera of controls nor from the gammaglobulin preparation used for treatment (not shown in the table). The specificity and the blocking effects of the eluted anti-Ig on peripheral blood lymphocytes of normal controls are shown in Table VI. It could be seen that the eluted material reduced the number of stained IgM cells and partially blocked the bind- ing of $\left[{ }^{12 \pi} \mathrm{I}\right]$ anti-IgM to same cells and in the presence of fresh guinea pig complement was partially cytotoxic. Cells that stained with the fluorescinated anti-IgG or capable of binding to the $\left[{ }^{125} \mathrm{I}\right]$ anti-IgG were, on the other hand, increased. The decrease and increase of Ig $\mathrm{M}$ and IgG binding cells, respectively, was more apparent upon use of $100 \mu \mathrm{g}$ of the eluted anti-Ig as compared with the use of $10 \mu \mathrm{g}$. The eluted material did not affect to any significant degree the number of stained IgA cells nor the binding capacity of cells to $\left[{ }^{125} \mathrm{I}\right]$ anti-IgA.

\section{DISCUSSION}

The primary goal of this study was to investigate the status of bone marrow-dependent (B) cells present in the bone marrow and blood compartments in disease states in which abnormalities of immunoglobulin ( Ig) synthesis were found: infantile agammaglobulinemia (I-AGG) and acquired AGG (A-AGG). An attempt was made to characterize the $B$ cell defects by studying the quantitative and/or qualitative abnormalities of the Ig receptors carried by these cells. Particular attention was paid to compare bone marrow $\mathrm{B}$ cells to blood $\mathrm{B}$ cells and to search for possible factors that could induce these defects.

Previous work from our laboratory had shown that in the human, immunocompetent cells present in the bone marrow are predominantly of the $B$ type and carry $\operatorname{Ig} M$ receptors $(1,8)$. In human blood there is a mixture of $\mathrm{B}$ and $\mathrm{T}$ cells $(2,14)$. The majority of receptors carried by the blood are of the IgG class and the minority are of $\operatorname{IgM}$ class $(10,14)$. Work from several laboratories had shown that the $\mathrm{B}$ cell originates from the bursa of Fabricius in the chicken (15) and probably from the bone marrow in the mouse (16) and man (1). The $B$ cells originating from these central lymphoid organs undergo successive maturation steps 
prior to acquisition of the capacity of secreting Ig (15, 17). Recent studies dealing with the ontogeny of the B system have indicated that IgM carrying cells are the first to appear in mice (7), chicken (17), and man (18). Administration of anti- $\mu$-chain antisera in the neonatal period in either the mouse or chicken model resulted in suppression of $\mathrm{B}$ cell differentiation with subsequent $\mathrm{AGG}$ in adult life $(6,7)$. Circulating anti- $\mu$ chain antisera were detected in these animals.

There had been recent interest in searching for circulating anti-Ig that could play a role in the pathogenesis of several lymphoproliferative $(12,19,20)$ and autoimmune diseases (21). Several patients with selective IgA deficiency were found to have in their serum anti-IgM of the $\operatorname{IgG}$ class $(22,23)$. Recently a high titer anti-IgG of the $\operatorname{IgM}$ class was detected in a patient with AGG with recurrent infections (24). In a recent study anti-IgM antibodies were detected in $23.8 \%$ of 18 patients with various types of immunodeficiencies (25). The role the anti-Ig plays in the pathogenesis of these diseases is not clear at the present time. In all these studies no attempt was made to study the biological significance of these anti-Igs.

In this study we have shown that in I-AGG the cell defect is due to the absolute lack of $B$ cells in both bone marrow and blood. This would probably indicate that the stem cell failed to differentiate to $\mathrm{B}$ cells during fetal life. The inductive forces controlling the differentiation and/or maturation of stem cell into B cells within the central lymphoid organ's microenvironment are unknown at the present time (26). Bone marrow of patients with the acquired form of AGG, on the other hand, contain B cells with Ig receptors that behaved in vitro both quantitatively and qualitatively in a fashion similar to that of normal control bone marrow. The main defect observed in patients with A-AGG in this report was at the level of blood B cells which exhibited fewer receptors, in all Ig classes. The demonstration of circulating anti-Ig $\mathrm{M}$ in these cases could be the factor responsible for decreasing the number of circulating IgM cells. The eluted anti-IgM of the IgG class was shown in this study to specifically bind to IgM cells of normal controls and thus reduced and increased IgM and IgG binding cells, respectively (Table VI). In the presence of complement the eluted anti-IgM was cytotoxic to the controls' cells. The source and/or the mechanism(s) responsible for anti-IgM production are unknown at the present time. Mutational changes and/or defective differentiation of the IgM cells of A-AGG patients induced by exogenous sources could be important factors. This speculation is supported by the frequent observations of increased incidence of autoimmunity (27) and lymphoreticular malignancies (28) in these patients.
Though studies from various laboratories have consistently demonstrated the absence of $\mathrm{B}$ cells in the peripheral blood compartment of patients with I-AGG $(13,30)$, few scattered reports have shown normal number of B cells in I-AGG (29) and in combined immune deficiency states (31). Similar studies on AAGG patients have shown conflicting results. Though some investigators have demonstrated absent $B$ cells in A-AGG peripheral blood $(13,29)$ others have shown normal numbers $(29,30)$. This could be attributed to the heterogeneity of this group of patients and/or to the severity of their disease. More work is needed to look for the variables in this disease and for possible B cell defects at various levels of maturation following their emigration from the central lymphoid compartment.

This study and several other recent publications (6, $12,17,24)$ will help in the understanding of clinical disease states associated with abnormal $\mathrm{B}$ cell function. Defects at one or more of the maturation steps of the stem cell to mature B cells have to be considered in antibody deficiency states. At the present there is an urgent need to understand the factor(s) that control $B$ cell differentiation, stem cell-microenvironment interaction and those that influence the migration of $B$ cells from the central lymphoid organ to the periphery.

\section{ACKNOWLEDGMENTS}

The excellent technical assistance of Miss Joan Kelley is appreciated. The work was supported by V.A. grants $642-$ 0030 and TR-39 and U. S. Public Health Service grant AI-00319. We thank Doctors D. Davis, M. Sprent, M. Guirgis, and J. Drobis for allowing us to study their patients. Discussions with Doctor D. C. Heiner during the early part of the work were valuable.

\section{REFERENCES}

1. Abdou, N. I., and N. L. Abdou. 1972. Bone marrow: the bursa equivalent in man? Science (Wash. D. C.). $175: 446$.

2. Wilson, J. D., and G. J. V. Nossal. 1971. Identification of human $\mathrm{T}$ and $\mathrm{B}$ lymphocytes in normal peripheral blood and in chronic lymphocytic leukemia. Lancet. 2: 788.

3. Davie, J. M., and W. E. Paul. 1972. Receptors on immunocompetent cells. V. Cellular correlates of the maturation of the immune response. J. Exp. Med. 135: 660 .

4. Taylor, R. B., W. P. H. Duffus, M. C. Raff, and S. de Petris. 1971. Redistribution and pinocytosis of lymphocyte surface immunoglobulin molecules induced by antiimmunoglobulin antibody. Nat. New Biol. 233: 225.

5. Good, R. A., W. D. Biggar, and B. H. Park. 1971. Immunodeficiency disease of man. Prog. Immunol. 1: 699.

6. Cooper, M. D., A. R. Lawton, and P. W. Kincade. 1972. A two-stage model for development of antibodyproducing cells. Clin. Exp. Immunol. 11: 143.

7. Lawton, A. R., R. Asofsky, M. B. Hylton, and M. D. Cooper. 1972. Suppression of immunoglobulin class synthesis in mice: I effects of treatment with antibody to $\mu$ chain. J. Exp. Med. 135: 277. 
8. Abdou, N. I., and N. L. Abdou. 1973. Immunoglobulin receptors on human leukocytes. III. Comparative study of human bone marrow and blood B cells. Role of IgM receptors. Clin. Exp. Immunol. 13: 45.

9. Campbell, D. H., J. S. Garvey, N. E. Cremer, D. H. Sussdorf. 1963. Complement titration. In Methods in Immunology. W. A. Benjamin, Inc., New York. 1st edition. 175 .

10. Abdou, N. I. 1971. Immunoglobulin receptors on human peripheral leukocytes. II. Class restriction of Ig receptors. J. Immunol. 107 : 1637.

11. McConahey, P. J., and F. J. Dixon. 1966. A method of trace iodination of proteins for immunologic studies. Int. Arch. Allergy. 29: 185.

12. Abdou, N. I., and N. L. Abdou. 1972. Anti-Immunoglobulins in multiple myeloma. Clin. Exp. Immunol. 11: 57.

13. Yvas, G. N., H. H. Fudenberg, H. M. Pretty, and E. R. Gold. 1968. A new rapid method for genetic typing of human immunoglobulins. J. Immunol. 100: 274.

14. Grey, H. M., E. Rabellino, and B. Pirofsky. 1971. Immunoglobulins on the surface of lymphocytes. IV. Distribution in hypogammaglobulinemia, cellular immune deficiency and chronic lymphatic leukemia. J. Clin. Invest. $50: 2368$.

15. Choi, Y. S., and R. A. Good. 1972. Development of chicken lymphoid system. II. Synthesis of primordial immunoglobulin $\mathrm{M}$ by the bursa cells of chick embryo. J. Exp. Med. 136: 8 .

16. Unanue, E. R., H. M. Grey, E. Rabellino, P. Campbell, and J. Schmidtke. 1971. Immunoglobulin on the surface of lymphocytes. II. The bone marrow as the main source of lymphocytes with detectable surface bound immunoglobulin. J. Exp. Med. 133: 1188.

17. Choi, Y. S., and R. A. Good. 1972. Development of chicken lymphoid system. I. Synthesis and secretion of immunoglobulins by chicken lymphoid cells. J. Exp. Med. 135: 1133 .

18. Lawton, A. R., K. S. Self, S. A. Royal, and M. D. Cooper. 1972. Ontogeny of B-lymphocytes in the human fetus. Clin. Immunol. Immunopathol. 1: 84.

19. Preud'Homme, J. L., and M. Seligmann. 1972. Antihuman immunoglobulin $G$ activity of membrane-bound monoclonal immunoglobulin $\mathrm{M}$ in lymphoproliferative disorders. Proc. Natl. Acad. Sci. 69: 2132.
20. Bonomo, L., F. Dammacco, A. Tursi, and D. Trizio. 1970. Waldenstrom's macroglobulinemia with anti-IgG activity: a series of five cases. Clin. Exp. Immunol. 6: 531.

21. Goldberg, L. S., and H. H. Fudenberg. 1971. Antiglobulins and human disease. Vox Sang. 20: 1.

22. Huntley, C. C., J. B. Robbins, A. D. Lyerly, and R. H. Buckley. 1971. Characterization of precipitating antibodies to ruminant serum and milk proteins in humans with selective IgA deficiency. N. Engl. J. Med. 284: 7.

23. Wells, J. V., J. F. Bleumers, and H. H. Fudenberg. 1972. Human anti-IgM iso-antibodies in subjects with selective IgA deficiency. Clin. Exp. Immunol. 12: 305.

24. Gelfand, E. W., H. Borel, A. I. Berkel, and F. S. Rosen. 1972. Auto-immunosuppression: recurrent infections associated with immunologic unresponsiveness in the presence of an auto-antibody to IgG. Clin. Immunol. Immunopathol. 1: 155.

25. Wells, J. V., J. F. Bleumers, and H. H. Fudenberg. 1973. Immunobiology of human anti-Ig M iso-antibodies. I. Clinical and serological studies. Clin. Immunol. Immunopathol. $1: 257$.

26. Metcalf, D., and M. A. S. Moore. 1971. Function of bone marrow lymphocytes and cell migration from the marrow. In hemopoietic cells. D. Metcalf and M. A. S. Moore, editors. American Elsevier Publishing Company, New York. 5 : 285.

27. Osoba, D. 1972. Thymic function, immunologic deficiency and autoimmunity. Med. Clin. North Am. 56: 319.

28. Waldmann, T. A., W. Strober, and R. M. Blaese. 1972. Immunodeficiency disease and malignancy. Ann. Intern. Med. 77:605.

29. Siegal, F. P., B. Pernis, and H. G. Kunkel. 1971. Lymphocytes in human immunodeficiency states: a study of membrane-associated immunoglobulins. Eur. J. Immunol. $1: 482$.

30. Cooper, M. D., A. R. Lawton, and D. E. Bockman. 1971. Agammaglobulinemia with B lymphocytes. Specific defect of plasma-cell differentiation. Lancet. 2: 791.

31. Preud'Homme, J. L.. C. Griscelli, and M. Seligmann. 1973. Immunoglobulins on the surface of lymphocytes in fifty patients with primary immunodeficiency diseases. Clin. Immunol. Immunopathol. 1: 241. 